Auf dem Weg zu einer Textsortendidaktik. Linguistische Analysen und text(sorten)didaktische Bausteine nicht nur für den fremdsprachlichen Deutschunterricht. Hildesheim, Zürich, New York: Olms, 2018. S. 149-164.

10. Hüllen W. Kleine Geschichte des Fremdsprachenunterrichts. Berlin: Schmidt, 2005. $254 \mathrm{~S}$.

11. Krumm H.-J. Lehrwerke im Deutsch als Fremd- und Deutsch als Zweitsprache-Unterricht. Deutsch als Fremd- und Zweitsprache. Ein internationales Handbuch. Berlin, New York: Edition, 2010. S. 1215-1226.

12. Piepho H.-E. Leseimpuls und Textaufgabe. Textarbeit im Deutschunterricht. Fremdsprache Deutsch. Jg. 2. 2005. S. 4-9.

13. Riedner R. Authentizität in der Fremdsprachendidaktik - kritische Anmerkungen $\mathrm{zu}$ einem problematischen Konzept. Deutsch als Fremdsprache. 2018. Jg. 55. S. 34-43.

УДК 81'243-25

DOI: $10.24144 / 2617-3921.2020 .18 .330-338$

Вікторія Леган

викладач кафедри іноземних мов ДВНЗ «Ужггородський національний університет» ORCID 0000-0003-0222-3120 м.Ужсгород, Україна, 0508849380 viktoriya.lehan@uzhnu.edu.ua

Наталія Годованець кандидат філософських наук,доиент дочент кафедри іноземних мов ДВНЗ «Ужггородський національний університет» ORCID 0000-0003-3429-6973 м.Ужггород, Україна, 0958789075 nataliia.hodovanets@uzhnu.edu.ua

\title{
The notion of communicative competence in the context of foreign language learning
}

Анотація. Стаття присвячена висвітленню та аналізу поглядів зарубіжних та вітчизняних учених та основні положення компетентності як структурного компонента іншомовної комунікативної компетентності. Розкривається сутність комунікативних понять у контексті оволодіння іноземними мовами. Здійснюється аналіз та порівняння структури та 
визначення комунікативної компетентності з-поміж досліджень. У статті описано поняття «комунікативна компетентність», а також ї̈ структура. Висвітлено види які були запропоновані як зарубіжними, так і вітчизняними дослідниками. Здійснюється аналіз поняття «комунікативна стратегія». Проаналізовано структуру та поняття іншомовної комунікативної компетентності як комплексу знань, умінь та навичок, які використовуються впродовж професійної діяльності. Також враховано даних аспект для самоосвіти та розвитку в изьому випадку майбутніх професіоналів. Основна мета вивчення іноземних мов - оволодіння іноземною мовленнєвою діяльністю. У процесі вивчення іноземних мов важливо усвідомлювати різницю між такими поняттями, як мова (знакова система), мовлення (процес спілкування через мову) та мовленнєва діяльність (єдність мови та мовлення). До складових комунікативної компетентності належать $i$ вміння усвідомлювати та долати комунікативні бар'єри. Саме цүі бар'єри можуть виникати, наприклад, при відсутності розуміння ситуації спілкування внаслідок різних поглядів, бачень (соияіальних, політичних, релігійних, фахових). Окрім того надалі існує неабияка потреба у дослідженні професійно-орієнтованого іншомовного спілкування, адже воно виступає основою в прочесі взаємодії з майбутніми фахівиями.

Актуальність досліджуваної теми визначається тим, щзо розвиток сучасного суспільства, встановлення взаємозв'язків та транскордонного співробітництва дедалі більше залежить від знання іноземних мов. Як наслідок іншомовне спілкування та співпраці між різними краӥнами світу, вимагає оновлення та суттєвих змін у методах та підходах до вивчення іноземних мов.

Ключові слова: комунікативна компетентність, складові, структура, функиії, стратегії, іншомовне спілкування.

Abstract. The article is devoted to the coverage and analysis of the views of foreign and domestic scholars and the main provisions of competence as a structural component of foreign language communicative competence. The essence of communicative concepts in the context of mastering foreign languages is revealed. The analysis and comparison of the structure and definition of communicative competence between researches is carried out. The article describes the concept of "communicative competence", as well as its structure. The species proposed by both foreign and domestic researchers are highlighted. An analysis of the concept of "communication strategy". The structure and concept of foreign language communicative competence as a set of knowledge, skills and abilities used during professional activity are analyzed. This aspect is also taken into account for selfeducation and development in this case of future professionals. The main purpose of learning foreign languages is to master foreign speech activity. In the process of learning foreign languages, it is important to be aware of the difference between such concepts as language (sign system), speech (the process of communication 
through language) and speech activity (unity of language and speech). Components of communicative competence include the ability to understand and overcome communication barriers. These barriers can arise, for example, in the absence of understanding of the communication situation due to different views, visions (social, political, religious, professional). In addition, there is still a great need for the study of professionally-oriented foreign language communication, because it is the basis in the process of interaction with future professionals.

The relevance of the research topic is determined by the fact that the development of modern society, networking and cross-border cooperation is increasingly dependent on knowledge of foreign languages. As a result, foreign language communication and cooperation between different countries of the world requires updating and significant changes in methods and approaches to learning foreign languages.

Keywords: communicative competence, components, structure, functions, strategies, foreign language communication.

Introduction. Given the processes of continuous development of relations and cross-border cooperation of the world demand modern methods of teaching. The main goal of teaching foreign languages should be the formation and development of foreign language skills of students in situations that are as close as possible to life and everyday realities, this contributes to their foreign language communicative competence. Therefore, the basis of communicative orientation is the opportunity to teach students to solve communicative problems to master communication in a foreign language at a high level. In other words, noting to "form skills and abilities to freely express thoughts and feelings in all speech activities: listening, reading, speaking, writing and in various spheres of communication: personal, public, educational, in other words to develop the communicative competence of the individual; to master the culture of speech" [10 p.15]. The purpose of the article is to study and define the essence of the concept of communicative competence and analysis of its structure in the context of teaching students to communicate in another language.

The tasks are: 1) to reveal the essence and structure, types of the concept of communicative competence and to analyze the features of the implementation of communicative competence in foreign language teaching.

Methods and methodology of the research. In the course of the research we used the methods of descriptive analysis, generalization, synthesis, as well as social, psychological and cognitive approach. In addition to the above, comparisons of previous studies and structural-functional analysis were used.

Presenting main material. The issue of communicative competence remains relevant for decades, as it is an integral part of the educational process. The first to introduce the use of the term communicative competence in science was the American linguist D. Hymes in 1972, whose theory concerned the definition of a dynamic category based on the unity of language and speech. According to D. 
Hymes, the essence of communicative competence is to understand the situational relevance of a language. Also, his theory states that the structure of communicative competence includes:

1) grammatical;

2) sociolinguistic;

3) strategic;

4) discursive competence.

This theory served as the first impetus for further progress in the field of foreign language teaching [ $6 \mathrm{p}$.213]. A significant contribution to the study of the theory of foreign language communicative competence in the 1980s was made by M. Canale and M. Swain [12, p. 42-47] (M. Canale and M. Swain). Their theory has gained widespread recognition and application. The essence of the theory is to identify four main types of competence, which, due to interacting with the system of knowledge and skills, form communication.

M. Canale and M. Swain identify the following competencies [12]:

- grammatical - the level of assimilation of grammatical material together with vocabulary stock, rules of spelling and pronunciation, sentence construction;

- sociolinguistic - the ability to use and understand grammar appropriately forms in different sociolinguistic contexts in order to perform individual communicative functions (description, messages, etc.);

- utterance competence - the ability to combine individual utterances in a logical and coherent message, using different syntactic and semantic means;

- strategic - the ability to use verbal and nonverbal means at the risk of effective communication in case of "insufficient" level of competence of the communicator.

Based on the analysis of various approaches to the interpretation of the concepts of "competence" and "competency", the Russian culturologist O. Sadokhin draws a number of important conclusions:

1) competence and competency are closely interrelated;

2) competence is derived from competency, but it characterizes the actual individual subject as the bearer of competence;

3 ) the quantity and quality of professional knowledge of the subject are a prerequisite for the effective implementation of its competence. [11p.54]

V. Barkasi, A. Gordeyev, S. Nikolaeva, O. Pavlyk and others paid significant attention to the formation of aspects of professional foreign language competence. It should be mentioned the structure of socio-cultural competence of T.M. Kolodkowhich includes country study competence (ability of the individual to be aware of knowledge about the people (native speaker), national character, traditions, customs and to acquire knowledge in the field of education, culture) and linguistic competence (ability of the student's personality to perceive, analyze, evaluate and use the received information about countries the world through acquaintance with their languages). N.I. Gaz points to the following components of communicative competence: 
1) verbal-communicative competence;

2) linguistic competence;

3) verbal cognitive competence;

4) meta-communicative competence.

In the process of learning foreign languages, it is important to be aware of the difference between such concepts as language (sign system), speech (the process of communication through language) and speech activity (unity of language and speech). The main purpose of learning foreign languages is to master foreign speech activities. The communication process must be effective and this effectiveness depends on the teacher-student relationship. In the context of the problem of communication efficiency and communicative competence, it is expedient to mention such a phenomenon in human interaction as a role that is a fixation of a certain position occupied by a participant in the system of interpersonal relations. [1;3;8] There are formal, intra-group, interpersonal and individual roles. In particular, a formal role is a behavior formed in accordance with the assimilated expectations of the environment associated with the performance of a particular social function (student, teacher, subordinate, leader, etc.). Intra-group role - is the behavior that is expected from the individual members of the group on a component basis of existing relationships. The main qualitative characteristic of effective communication is the focus - the orientation of the individual, first of all, on the positive qualities in another person, which helps to reveal the personal potential of the participant with whom we communicate. Emphasis, in particular, is placed on cognitive processes in the structure of communicative competence. This is, first of all, thinking - the ability to analyze actions, to see the motives that motivate them. Factor of successful communication is also a socio-psychological perception, which includes identification, empathy, social reflection. Thus, we can say that communicative competence includes not only the personal characteristics of the individual, but also in some way organized cognitive processes and emotional (affective) sphere. Components of communicative competence include the ability to understand and overcome communication barriers that may arise, for example, in the absence of understanding of the communication situation due to different views, visions (social, political, religious, professional). Barriers to communication can also be psychological in nature, reflecting the individual psychological characteristics of those who communicate, their established relationships: from friendship to hostility to each other. [2] As well as sociability (ability to establish and maintain the necessary contacts with other people);

- possession of meaningful information and the ability to operate on it;

- ability to partner and achieve mutual understanding.

In contrast to the above, the causes of poor communication can be:

- stereotypes - simplistic opinions about individuals or situations, resulting in a lack of objective analysis and understanding of people, situations, problems; 
- oversaturation of the communicative space with information prevents the adoption of relevant decisions, leads to unnecessary emotional overload, thereby complicating relationships with others;

- "prejudices" - the tendency not to take into account what is contrary to their own established views, what is new, unusual ("We believe in what we want to believe"). One seldom realizes that another person's interpretation of events is as legitimate as his own interpretation;

- bad relationships between people - if a person's attitude is hostile, it will be very difficult to convince him of the fairness of your view;

- lack of attention and interest of the interlocutor, and interest arises when a person realizes the importance of information for themselves: with this information you can get what you want or prevent unwanted developments;

- disregard for the facts, i.e. the habit of drawing conclusions in the absence of a sufficient number of facts;

- errors in the construction of statements: incorrect choice of words, the complexity of the message, weak persuasiveness, illogicality;

- wrong choice of communication strategy and tactics.

As well as any of the professional competencies, the communicative competence of the teacher is determined by at least three components:

- cognitive (what the specialist knows about this issue);

- operating room (as a specialist realizes his knowledge in practice);

- motivational (how a specialist relates to a certain area of their own activities).

For each of the participants in the educational process, the quality and outcome of professional interaction will be determined:

- orientation of the individual (orientation to another person, to joint activities, the desire to understand it, to maintain relationships);

- pedagogical tact and style of communication (the share of responsibility assumed by the participants of joint activities should be adequate to contribute to the end result, and forms of communication should reflect not only social status but also other subjective qualities of the individual);

- the level of tolerance (personality trait, which implies its protection from the effects of adverse factors, the formation of electoral tolerance of adverse actions without reducing adaptive capabilities, manifestations of endurance, self-control).

There are many strategies, among which it is worth noting the communication strategies of T. Van Dyck and W. Kinch, which are considered common and include the following:

1) local connectivity strategies are aimed at establishing links between the facts set out in the proposals;

2) stylistic strategies as those that allow to select and interpret language tools according to the context;

3) rhetorical strategies as those that increase the effectiveness of verbal communication contribute to the understanding of discourse; 
4) non-verbal strategies as those necessary for the processing of non-verbal information;

5) macro-strategies as such that allow the addressee to guess the general subject of the message, receiving only a minimum of information;

In the practice of communication, strategic competence is realized by important communicative skills to change one's own speech behavior according to the specific situation of foreign language professional communication [4].

Communicative competence is always acquired in a social context. It requires the individual to realize:

- own needs and value orientations, techniques of their work;

- willingness to perceive the new in the external environment;

- its capacity to understand the norms and values of other social groups and cultures (real internationalism);

- own feelings and mental states in connection with the action of environmental factors;

- ways to personalize the environment.

Thus, the communicative competence of a person is considered as an ideological and moral category, regulates the entire system of human relations to the natural and social world, as well as to himself as a synthesis of these two worlds.

Communicative competence involves the formation of relevant knowledge, skills and qualities of the specialist, which contribute to effective interaction with other subjects of the pedagogical process and the ability to solve problems of pedagogical activity in the process of communication on an interpersonal basis. The communicative competence of a future foreign language teacher is based on knowledge of the rules and norms of communication by means of foreign and native language and sensory experience that allow to navigate in situations of pedagogical communication, understand motives, intentions, strategies of human behavior.The content of communicative competence is also formed by communicative skills, which, according to L. Karpova [7, p. 37], help the teacher to communicate with students, colleagues, exchange information and on this basis to establish pedagogically appropriate relationships with them. Communication skills are interconnected groups of perceptual skills, verbal communication skills and pedagogical technique skills. Perceptual skills are manifested at the initial stage of communication, it is the ability to understand students and colleagues. To implement these skills in practice requires knowledge of the value orientations of others. The actual ability of verbal communication involves, first, attracting attention (through speech, pauses, clarity), establishing psychological contact with the audience (to convey information and perception of students) and management of communication in the pedagogical process. Possession of pedagogical techniques provides effective interaction with students in any situation, they are an external form of teacher behavior and help him/her to create his/her own professional image, i.e. a set of visual, internal, verbal and acting images. 
Developing the communicative competence in English as a foreign language where English is taught as a foreign language is an aim that learners struggle to achieve. Achieving such an aim depends on many factors related to teachers, teaching situation, environment and learners themselves as well. There are many learning strategies and activities that are usually selected for enhancing language learning. These activities that enhance language learning are usually communication-based activities and task-based activities. These activities usually play a big role in developing communicative competence and enabling communication skills in comparison to those strategies of imitations, memorization and repetition drills that mainly concern about language and its structures rather than the use of that language. A new trend in the last third of the last century was the emergence of the Communicative Language Teaching Approach that recommends teaching English through communication or by using it.

Prospects for further research are to study the theoretical and methodological basis for the formation of strategic communicative competence in foreign language communication of future professionals in higher education.

Conclusions. Communicative competence is based on knowledge of the rules and norms of communication by means of foreign and native language and sensory experience, which allow to navigate in situations of pedagogical communication, to understand the motives, intentions, strategies of human behavior. Researcher (A. Hadley) [5, p.79-86] in her work "Teaching language in context" emphasizes the fact that foreign language competence is the basis of communicative culture of a person who is directly involved in learning a foreign language.

In particular, A. Hadley emphasizes that the communicative culture necessarily includes the already formed foreign language competence, i.e. internal readiness, as well as the ability to communicate effectively in a foreign language. Communicative competence requires pre-formed relevant knowledge, skills and qualities of a specialist, which will promote effective interaction with other subjects of the pedagogical process and help to solve problems of pedagogical activity in the process of communication on an interpersonal basis. The communicative competence of a future foreign language teacher is based on knowledge of the rules and norms of communication by means of foreign and native language and sensory experience, which allow to navigate in situations of pedagogical communication taking into account the structure, components and types of communicative competence and communication strategies.

\section{REFERENCES}

1. Андреева Г. М. Социальная психология: учебник для вузов: 5-е изд., испр, и доп., М.: Аспект Пресс, 2008. 365 с.

2. Бодалев А. А. Личность и общение : Избранные психологические труды / 2-е изд., перераб. М.: Международная педагогическая академия, $1995.328 \mathrm{c}$. 
3. Гез Н.И.Формирование коммуникативной омпетенции как объект зарубежных методических исследований. Иностранные языки в школе. Москва, 1985. №2. С. $17-24$.

4. Dyck T.A. van, Kinch V. Strategies for understanding a coherent text. New in Foreign Linguistics. M .: Progress,1988. Issue 23. P.153-211.

5. Hadley A.O. English in context: textbook. way. Illinois: Heinle\&Heinle, 1993. P. 79-86.

6. Hymes D.H. On communicative competence. Philadelphia: University of Pennsylvania Press, 1971. 213 p.

7. Карпова Л.Г. Формування професійної компетентності вчителя загальноосвітньої школи: дис. ... канд. пед. наук: 13.00.04 / Харківський держ. педагогічний ун-т ім. Г.С.Сковороди. Харків, 2003. 207 с.

8. Колодько Т.М. Формування соціокультурної компетенції майбутніх учителів іноземних мов у вищих педагогічних навчальних закладах: автореф. дис. канд. пед. наук: 13.00.04/ Нац пед. ун-т ім. М. П. Драгоманова. Київ, 2005. - 24 с.

9. Ніколаєва С. Ю. Цілі навчання іноземних мов в аспекті компетентісного підходу. Іноземні мови. Київ, 2010. № 2. С. 11-58.

10.Пассов Е.И. Культурообразная модель профессиональной подготовки учителя: философия, содержание, реализация. Иностранные языки. Москва, 2002. №4. С. 18-21.

11.Садохин А.П. Межкультурная коммуникация: учебное пособие М. : Альфа - М : ИНФРА, 2004. 288 с.

12. Swain M., Canale M. Theoretical basis of communicative approaches in the process of teaching a second foreign language: applied linguistics. Oxford: Oxford University, 2002. $47 \mathrm{p}$. 